\title{
FACTORS DETERMING THE FOOD INSECURITY STATUS OF RURAL HOUSEHOLD IN MANNA WOREDA OF JIMMA ZONE, ETHIOPIA.
}

\section{FACTORES QUE DETERMINAN EL ESTADO DE INSEGURIDAD ALIMENTARIA DEL HOGAR RURAL EN LA ZONA MANA WOREDA DE JIMMA, ETIOPÍA.}

\author{
Meskerem Million* and Mequanent Muche \\ Jimma University, Ethiopia, *Corresponding author: meskerem.milion69@gmail.com
}

\section{ABSTRACT}

This study was conducted in Manna woreda of Jimma zone. It is found at a distance of $368 \mathrm{~km}$ south west of Addis Ababa and $24 \mathrm{~km}$ west of Jimma town. The main objective of the study was to identify the determinants of household food insecurity in rural households and a total number of 200 sample households were selected as sample respondents. Interview schedule and focus group discussions with a member of 8-10 individuals were among primary sources which were used to collect primary data and different electronics sources and other documents from the woreda office were used as secondary data source of the study. To know the food security status of the households, the data collected from sampled respondents regarding food preparation for seven day recall and daily consumption record were converted to kilocalorie using the Food Composition table manual. Descriptive statics such as: Mean, frequency distribution and percentage were used to examine the demographic and socio economic status of the sample respondents. Binary logistic regression model was used to identify the determinant factors of household food insecurity. Accordingly Large family size, asset possession, sex of the household head, number of oxen owned, Access to improved seed and chemical fertilizer were found to be the determinants of food insecurity in the area, Existence of major animals diseases and pest that affect crop production were also found to significantly determine individuals food insecurity status. In addition, some of the coping strategies that are used by food insecure household were assessed. Their local coping strategies at initial and severe stage includes: sale of livestock and productive assets as well as marketing of wood/charcoal which can in turn aggravate the problem of food insecurity. Key words: Food security, Households, Determinants, Coping strategy

\section{RESUMEN}

Este estudio se realizó en Manna woreda de la zona de Jimma. Se encuentra a una distancia de $368 \mathrm{~km}$ al suroeste de Addis Abeba y a $24 \mathrm{~km}$ al oeste de la ciudad de Jimma. El objetivo principal del estudio fue identificar los determinantes de la inseguridad alimentaria de los hogares en hogares rurales y se seleccionó un total de 200 hogares de muestra cómo encuestados de muestra. El horario de la entrevista y las discusiones de los grupos focales con un miembro de 8-10 individuos se encontraban entre las fuentes principales que se utilizaron para recopilar datos primarios y se usaron diferentes fuentes electrónicas y otros documentos de la oficina de woreda como fuente de datos secundaria del estudio. Para conocer el estado de seguridad alimentaria de los hogares, los datos recopilados de los encuestados de la muestra con respecto a la preparación de alimentos para el retiro de siete 
días y el registro de consumo diario se convirtieron a kilocalorías utilizando el manual de la tabla de Composición de Alimentos. Se utilizaron estadísticas descriptivas tales como: media, distribución de frecuencia y porcentaje para examinar el estado demográfico y socioeconómico de los encuestados de la muestra. Se utilizó el modelo de regresión logística binaria para identificar los factores determinantes de la inseguridad alimentaria en los hogares. En consecuencia, el tamaño de la familia numerosa, la posesión de activos, el sexo del jefe de familia, la cantidad de bueyes que poseía, el acceso a semillas mejoradas y fertilizantes químicos fueron los determinantes de la inseguridad alimentaria en el área, la existencia de enfermedades y plagas de animales importantes que afectan la producción de cultivos También se descubrió que determinan significativamente el estado de inseguridad alimentaria de las personas. Además, se evaluaron algunas de las estrategias de afrontamiento que utilizan los hogares con inseguridad alimentaria. Sus estrategias locales de afrontamiento en la etapa inicial y severa incluyen: la venta de ganado y activos productivos, así como la comercialización de madera / carbón que a su vez puede agravar el problema de la inseguridad alimentaria.

Palabras clave: seguridad alimentaria, hogares, determinantes, estrategia de afrontamiento.

\section{INTRODUCTION}

Ethiopia is a country situated at the eastern part of Africa. Report of the central statics agency shows that, the country is the second most populous country in Africa with more than 100 million populations (CSA, 2007; Eshetu, 2017) where the majority of the people (80\%) live in rural areas. Agriculture plays a vital role in the country's economic development. As it is indicated in the United Nations development program(UNDP)and Central statistics agency (CSA) report, agriculture contributes around $85 \%$ of employment, $43 \%$ of GDP and $70 \%$ of the country's export (CSA, 2010; UNDP, 2014).

Ethiopia has been facing many challenging problems ranging from those induced by environmental crises to those caused by demographic and socio-economic constraints that adversely affect peoples' production system. The country is among the poorest and one of the most food insecure countries in the world where $44 \%$ of its population live below the national poverty line and $46 \%$ of its population get below the minimum levels of dietary energy consumption compared with other sub-Saharan and other developing countries (Mesas, 2010; Frehiwot, 2007).

Rural households in Ethiopia frequently face food security problems because of different factors such as factors related with socio economic, agro ecological, cultural and demographic features. For instance in 2011, it is well remembered that the horn of Africa drought left 4.5 million people in need of emergency food assistance in Ethiopia. Pastoralist areas in southern and south-eastern part of the country have been worst affected by the drought. Further, cereal markets had a supply shock and food prices rose above 2008 levels resulting in high food insecurity among poor people. Similarly in 2014, Food and Agricultural Organization (FAO) report revealed that nearly 33 million people were suffering from chronic undernourishment and food insecurity which indicated that Ethiopia has one of the highest levels of food insecurity in the world (FAO, 2014).To address this problem, the government of Ethiopia was taking a strong leadership role with programs that meet the varying needs of vulnerable households. However the impacts of most of these policies have been shadowed (United Nation, 2010). 
The latest Food and Agricultural Organization (FAO) estimate indicated that about 795 million people in the world were estimated to be chronically undernourished in 2014-16. In the same period, the prevalence of under nutrition has fallen from $18.6 \%$ (1011) to $10.9 \%$ (795) globally, from $23.3 \%$ (991) to $12.9 \%$ (780) for developing countries and from $47.2 \%$ (104) to 31.5\% (124) for Eastern Africa despite significant population growth (FAO, 2015). The five African countries with the most number of people in a state of hunger/under nourishment has between 10 million and 32 million people i.e. Ethiopia 32.1 million; Tanzania 15.7 million; Nigeria 12.1 million; Kenya 11 million and Uganda 10.7 million (Endalew, 2015).

Significantly, four out of the five countries with the most number of people affected by hunger/undernourishment are in the Horn / East of Africa (Ethiopia, Tanzania, Kenya and Uganda). According to world meteorological organization report, around 10.7 million people are currently food insecure across Somalia, Kenya, Ethiopia and Karamojong region in Uganda. Although the number of food insecure population is lower than numbers observed during the drought of 2017 (15.3 million people), there is a high risk of a worsening situation due to forecasted rainfall deficits (WMO, 2019).

A number of previous studies on food security situation of Oromia regional state suggested that Oromia is among the food insecurity affected areas in Ethiopia. According to Haile,et al. (2005), in Oromia this problem is occurred due to climatic factors and other agro ecological factors and in relation to this different printed and unprinted sources shows that, rural households in Jimma zone of Oromia region also have been suffered by serious food insecurity problems. Therefore based on this truth conducting the study was found to be crucial as the information provided will enable effective measures to be undertaken and improve food security status and bring the success of food security development programs. It was also believed to benefit practical researchers as a reference material in addition to providing better back ground about the determinants of food insecurity for policy maker, for agricultural office in the zone and other immediate development workers at different level

\section{MATERIAL AND METHODS}

Description of the study area: The study was conducted in Jimma zone which is located $355 \mathrm{~km}$ to the South west of Addis Ababa. The zone is characterized by a tropical highland climate with heavy rainfall, warm temperatures and a long wet period. It is one of the 18 zones of Oromia national state. It has suitable climatic condition for agricultural production mainly coffee. Manna is one of the woredas that are found in Jimma zone.It is located at 368 $\mathrm{km}$ south west of Addis Ababa and $24 \mathrm{~km}$ west of Jimma town. It has an area of about 400 $\mathrm{Km}^{2}$ and one urban center, i.e., Yebu town, district capital. The Woreda has common boundaries with LimuKossa, Kersa, SekaChekorsa and Gomma districts. Topographically, it is characterized by mountains (Weshi and bebella mountain), dissected plateaus, and Plains Rivers, such as Aniso, Doha, Wanja, Yebu, Sogido, etc., and intermittent streams like Awaso, Urgeyi, etc., are flowing through the Woreda.

According to the information that is found from Jimma zone agricultural office, the Woreda is classified into dega (12\%), Woinadega (63\%) and kolla (24\%) agro climatic zones. High forest, woodland, reverie and plantation forests are available in the district. The rainy season extends from May to September with highest rain fall usually recorded in August. The mean annual rain fall varies between 800 and 2000 millimeters. 
Data and Data Sources:Both qualitative and quantitative data were collected from primary and secondary sources toidentify important variables that affect household food security. Thus, primary data were collected using household survey, in which the household heads and their spouses were asked about food security and related issues. On the other hand, secondary data were obtained from printed and electronic sources.

The main data collected for this study include household demographic characteristics, socio economic characteristics, asset possession, off-farm/non-farm income, livestock and oxen ownership, , and types and amount of food eaten by the household in a specific period (seven days in this case ). The range of coping strategies practiced by households was also assessed at different levels. Other additional data were also collected including resource endowment, accessibility of farm inputs and extension service and problems of crop production.

Sampling Technique: An important decision that has to be taken while selecting a sampling technique is about the size of the sample. Appropriate sample size depends on various factors relating to the subject under investigation including time, cost and degree of accuracy (Gupta etal., 2002; Muquanent, 2009).

As it is practically impossible to reach all individuals or communities in the study area because of the limitations of transport, time and money it is wise to take representative samples to collect useful data. In line with this, a multi stage sampling procedure was used to select sample households. In the first stage, Manna woreda was selected purposively and 2 Kebeles (Dowa and HundaToli) were selected among 27 Kebele Administrations using a random sampling technique. Finally, as the household was considered as basic sampling unit, a total of 200 households were selected from Hundatoli and Dowa Kebeles, respectively, using probability proportional to sample size-sampling techniques (PPS).

Method of Data Collection: The data was collected from sampled households by different methods i.e. Primary data were collected from sampled households where principal person responsible for preparing meals or household heads were asked how much food was prepared (for a week) for consumption and related issues food insecurity using survey questioner. For this purpose exhaustive list of food items were prepared and it was asked to the person who was considered as most knowledgeable to this activity (preparing food for household consumption) or house hold heads. On the other hand, secondary data were collected from internet and some relevant woreda offices.

Method of Data Analysis: The data obtained from sampled respondents regarding food preparation for seven day recall and daily consumption record were converted to kilocalorie using the Food Composition Table Manual (EHNRI, 1997:Mequanent, 2009).Subsequently, the converted data were divided to household $A E$ and by the days in the weak in order to get the amount of kilocalorie consumed by individually in one day. Following this, the amount of energy in kilocalorie ( $\mathrm{kcal}$ ) available for the household was recorded. Then after, the results obtained were compared with the minimum subsistence requirement per AE per day (i.e. 2100 kcal).

Households who consume below this minimum requirement ( $2100 \mathrm{kcal}$ per AE per day) were categorized as food insecure and those households who consume above the threshold were considered as food secure. After identifying the households as food secure and insecure groups, the next step was identifying the demographic and socio economic variables that were assumed to have association with food security. In light of this, major demographic, 
socioeconomic and institutional variables were assessed to look into their relative importance in determining the state of food security at household level.

Generally the data was analyzed by employing SPSS version 22 and descriptive statistics such as mean, frequency, standard deviation, table, and graphs were utilized in order to analyze the information obtained from sampled households and statistical t- test value is examined whether there is a significance mean difference between food secured and insecure households in order to decide whether continues variable has direct or inverse relationship with food insecurity or not. In addition the statistical chi-square value was also examined in order to identify whether there is significant association between the discrete variables and household food insecurity. The local coping strategies employed by the house hold was compared with their priority rank of the households and the strategies used by many households decided to be first and second etc.

\section{RESULTS AND DISCUSSION}

Food insecurity situation of the Households: Food insecurity at household level basically measured in number of ways. However, this study particularly focus on measuring food insecurity situation in consideration with household caloric consumption in which the exhaustive food items are listed for sampled households in respective with their sources home produced and purchased. Household caloric acquisition is a measure of the number of calories, or nutrients available for consumption by household members over a defined period of time

Households were asked what food items they were used for their consumption process and what amount of each food items they consumed in one week in household members. According to Guled (2006), seven days recall period is appropriate due to the fact that it is recent to recall of the food items served for the household. Sequentially the food items that were used by household members as consumption, which were given in local units were converted in to standard units $(\mathrm{Kg})$ and followed by kilocalories in order to get the total amount of food that is consumed by household members for seven days.

The total amount of food items that were obtained in kilocalories for the household members in one week was divided by the number of days in the week as well as by AE (adult equivalent) in order to get the amount of calorie provided for each individual in the household. After the amount of calorie acquisition for individuals in the household members were identified it was compared with the minimum subsistence requirement recommended by Ethiopian health and nutrition research center calorie of $2100 \mathrm{kcal}$ per AE per day. Depending on the result obtained from this calculation the households was decided to be categorized under food secured and insecure in such a way that households who consume less than 2100 kcal per AE per day is food insecure whereas households consume above 2100 kilocalorie per $A E /$ day is categorized as food secure .

Finally, from the survey result the percentage of food secured and insecure households were found to be $57.5 \%$, and $42.5 \%$ respectively. The mean value energy available for food insecure and secure households was $1418 \mathrm{Kcal} / \mathrm{AE} /$ day and $3366 \mathrm{Kcal} / \mathrm{AE} / \mathrm{day}$, respectively. The minimum and maximum energy available for food insecure households was $897 \mathrm{Kcal}$ per AE per day and $2090 \mathrm{Kcal}$ per AE per day, respectively whereas the minimal and maximum energy intakes of food secure households were $2220 \mathrm{kcal}$ per AE /day and $5012 \mathrm{Kcal}$ per $\mathrm{AE} /$ day per, respectively. The mean energy intake of all sample/ households was $3964 \mathrm{kcal}$ 
per AE/ day. The $t$ value (10.5) shows that there is a significant mean difference between food secure and insecure households as it is clearly showed in the table(2).

Descriptive statistics of continuous variables: This sub section presents descriptive statistics of continuous variables which can be clearly described by numbers and its means with regard to $t$-value in order to identify whether there is a significant mean difference between the food secured and food insecure households in regard with those variables. The variables include age of household head, family size and, land holding, total assets birr, and number of oxen

Age of the household head: Age is one of the continuous variables which can be expressed in terms of means. In this study it was assessed in order to identify whether it has detrimental relationship with the food insecurity situations in the study area or not. With regard to this the age of the sampled household in the survey area was identified particularly one by one and examined wither it has direct relationship with the food insecurity situation of the households or not. Accordingly the average age of the sampled household was 50 years where as the minimum and maximum age of the respondents were 20 and 80 respectively. the percentage of food insecure and secure households were found to be $42.5 \% 57.5 \%$, The study covered with 200 households in which $25 \%$ households were females and $75 \%$ households were men households. From survey result the average age and standard deviation of food secure and insecure households were 43(14) and 44(12) respectively. Accordingly the t- value $(.25)$ calculated reflects that there is no statistically significant mean difference between the food insecure and secure household head with respect to age in the survey area. This result is in line with the study conducted by LopézCarr, et al., (2017) where there was no a significant relationship between age and food security or insecurity status of the household. But other studies such as (Abu and Soom, 2016; Oyekale, et al., 2017; Ehebhamen, et al., 2017; Zhou, et al., 2019) shows the positive relationship of age with food insecurity or negative relationship of age with being food secured household which means as the age of the household head increases the food insecurity situation of the household also increases.

Family size or adult equivalent: Family size is the other continues variables that can be expressed by numbers as well as by its means so it was assessed to check whether it has linkage with food insecurity situation of sampled households. Accordingly the minimum and maximum number of family size is found to be 2 and 9 respectively with respect to the specific characteristics of food secure and insecure households, impact determining the state of food security in such a way household with large family size tends to be food insecure than those with small number of family size. In light of this the statistical analysis of $t$-value(8) showed that there is a significant mean difference between food secure and food insecure which is 3 and 6 respectively. The standard deviation of food secured and insecure households $(2,1)$ also states that there is statistical difference among food secured and insecure households. This shows that family size have positive relationship with the state of households food insecurity in the survey area this finding is supported by (Bose, 2018; Teklay, et al., 2015; Khan et al., 2018) where in their study they have found a negative relationship of food security with family size. In other word when the family size increase the probability of the family to become food insecure increases. On the other hand this finding is on contrary to other findings that shows a positive relation of family size with food security or a negative relationship of family size with food insecurity (Shumetie and Alemayehu, 2019 and Joshi G and Joshi N, 2016) 
Educational status of the household: Sampled respondents in the study area were categorized under different educational levels i.e. no formal education, those who can read and write and who can read (educated from grade $0-5$ ). The mean and standard deviation of total sampled households is 1 and 1.4, respectively whereas $1(2)$ and $1(1)$ is the mean and standard deviation of food insecure and secured households, respectively. Accordingly the statistical analysis of the t-value showed that there is no significance association between the educational status and food insecurity of the households in the area(table3).This finding is similar with the study of Aidoo,et al., (2013) where they have also found no significant relationship between educational status and being food unsecured. On the other hand, other studies conducted by Titus and Adetokunbo (2007); Abu and soom, (2016); Sseguya, et al., (2018) have found a negative relationship between education and household's food insecurity.

Assets owned by the sampled households: Asset is also another continuous variables and household resources which have serial relationship with the food security situation. This means that the amount of assets possessed by the households determine whether individuals or households have the chance to be food secure and in secure. Insight of this the minimum and maximum asset owned by sampled hose holds in birr is found to be 290 and 20000, respectively. Whereas the mean and standard deviation of food secured and insecure households is 6184 (5306) and 963(713) respectively. The statistical analysis of the t-value realizes shows that there is the significance difference between the mean of food secured and food in secured households in such a way that households who own high amount of assets in birr have the chance to be food secure than those who own low amount of assets in birr. This finding is in line with Gebre (2012); Beyene and Muche (2010);Bogale and Shimelis(2009); Diallo and Toah(2019).

Land holding by sampled households: Farm land is the major resource in agricultural society and it was assessed in this study to identify whether land holding and its size determine households to be food insecure or not. From survey result the maximum and minimum of land size owned by the sampled respondents were 0 ha and 6 ha respectively. The mean and standard deviation of the food secured and insecure households were 2(.5) and the statistical analysis of the t-value (1.38) shows there is no significance difference between the mean values of the food secured and insecure households in the study area. This implies that the amount of land owned by the household do not determine whether the house holds to be food secure or not. This is in contrary with the findings of Maharian and Khatri (2006); Beyene and Muche (2010); Abafita (2014) where they have found the positive effect of land holding on the food security status of the households or its negative relationship with the probability of being food insecure.

Oxen owned by sampled respondents: Oxen are the most valuable units of wealth that farmers possess (Yared, 1999; Mequanent, 2009). Sample respondents perceive that if a household has a pair of oxen he is considered as independent and self-reliant. Mostly oxen are the draft animals that the rural households have to own in order to be self-sustenance. Accordingly the minimum and maximum number of oxen owned by total sampled households, the mean and standard deviation of food secured and insecure groups is $0(4), 2(1)$ and $0(0)$ respectively. In light of this the statistical analysis of the $t$-value showed that there is a significant difference between the mean of food secured and insecure households which implies that households who own many number of oxen is to be food secure than those households with low number of oxen. Therefore, in the study area as the numbers of oxen 
owned by the households increase their probability to become food secured also increases in other word this variable has a negative relationship with household food insecurity. This result is in line with Muche, et al., (2014); Tefera T. and Tefera F (2014); Leza and Kuma (2015). Table 2. Energy available per AE per day among sample households

\begin{tabular}{|c|c|c|c|}
\hline Energy available per AE in (kcal) & Food insecure(85) & Food secure(115) & Total $(\mathrm{N}=200)$ \\
\hline Minimum & 897 & 2220 & 897 \\
\hline Maximum & 2090 & 5012 & 5012 \\
\hline Mean & 1418 & 3366 & 3964 \\
\hline Mean difference & & 1948 & \\
\hline (SD) & 417 & 713 & 1132 \\
\hline T-value & & & $-10.5 * * *$ \\
\hline
\end{tabular}

Table 3. Descriptive Statistics of Continuous Variables

\begin{tabular}{|c|c|c|c|c|c|}
\hline \multirow[b]{2}{*}{ Variables } & \multicolumn{2}{|c|}{ Total HHs (200) } & \multirow{2}{*}{$\begin{array}{l}\text { Food Insecure } \\
\text { (85) HHS } \\
\text { Mean (SD) }\end{array}$} & \multicolumn{2}{|l|}{ Food secure } \\
\hline & Min/Max & Mean (SD) & & Mean (SD) & t-value \\
\hline Age & $20(80)$ & $43(13)$ & $44(12)$ & $43(14)$ & $.25(\mathrm{NS})$ \\
\hline Family size(AE) & $1(19)$ & $4(2)$ & $6(1)$ & $3(2)$ & $8 * *$ \\
\hline Caloric & $897(5012)$ & 2.5E3(1132) & 1418.471 & 3366.696 & $-10.5^{* * *}$ \\
\hline \multicolumn{6}{|l|}{ Consumption } \\
\hline Educational Level & $0(5)$ & $1(1.4)$ & $1(2)$ & $1(1)$ & .295 (NS) \\
\hline Total asset in birr & $290(20000)$ & 4E3 (4788) & $963(5306)$ & $6184(713)$ & $4 * * *$ \\
\hline Land Holding & $0(6)$ & $1.5(1.96)$ & $2(.5)$ & $2(.5)$ & $1.38(\mathrm{NS})$ \\
\hline Number of Oxen & $0(4)$ & $1(2)$ & $0(0)$ & $2(1)$ & $7 * * *$ \\
\hline
\end{tabular}

Descriptive Statistics of Discrete Variables: This sub section comprises the discrete variables which cannot be explained by means of the households and can be expressed by percentage i.e. sex of the households, extension service, improved seed ,chemical fertilizer, agrochemicals, organic fertilizers, source of income and production problems were the variables that were covered in this section.

Sex of the household: Sex of the household head is one of the discrete variables that cannot be explained in means but in percentage. In this study it was assessed in order to examine whether the sex has significant relationship with the household food insecurity in survey area. In this case the survey includes total number of 200 in which $75 \%$ of them were male and $25 \%$ of them were female households. From statistical data analysis, it was found that about $58 \%$ of food insecure and $87 \%$ of food secure were male headed households where as $42 \%$ of food insecure and $13 \%$ of food secure were found to be female headed households (table 3).Accordingly there is statistical chi-value analysis shows that there is a significance relationship between food security and sex in which male households have the chance to be food secure than female households in the study area. On the other hand the probability of female headed households to be food insecure is higher compared to male headed households. This result supports the finding of the study by Omotayo, et al., (2018); Tibesigwa and Visser (2016); Mallick and Rafi (2010). On the other hand the study conducted 
by Szabo et al., (2016) shows no significant relationship of household food security with sex of the household head.

Agricultural input services and Extension: This section was aimed to assess the provision of agricultural inputs like chemical fertile, organic fertilizer, agrochemicals and organic chemicals as well as the extension services in the study area. In this study those variables were assessed in order to examine the association between food insecurity and existed variables.

From the survey result the extension service provided is not determine whether the house hold is to be food secure and insecure. Accordingly $88 \%$ of food insecure and $96 \%$ food secure were households those use extension service where as $12 \%$ and $4 \%$ were food insecure and food secure households who do not use extension services, respectively. In light of this the statistical analysis of the chi-square shows that there is no significance association between the percentage food secured and insecure households in respective with extension (table 4).

Table 4. Descriptive Statistics of Discrete Variables

\begin{tabular}{|c|c|c|c|c|}
\hline Description of variables & Categories & Food Insecure (\%) & Food Secure (\%) & Chi square Value \\
\hline \multirow[t]{2}{*}{ SEXHH } & Male & 58 & 87 & $4.126 * *$ \\
\hline & Female & 42 & 13 & \\
\hline \multirow[t]{2}{*}{ EXTUSER } & Yes & 88 & 96 & $.775(N S)$ \\
\hline & No & 12 & 4 & \\
\hline \multirow[t]{2}{*}{ OXENOWN } & Yes & 0 & 83 & $26.75^{* * *}$ \\
\hline & No & 100 & 17 & \\
\hline \multirow[t]{2}{*}{ IMPRSEED } & Yes & 12 & 89 & $32.5 * * *$ \\
\hline & No & 88 & 11 & \\
\hline \multirow[t]{2}{*}{ INONFARM } & Yes & 65 & 57 & 273(NS) \\
\hline & No & 35 & 43 & \\
\hline \multirow[t]{2}{*}{ INCFROFF } & Yes & 53 & 61 & $.25(\mathrm{NS})$ \\
\hline & No & 47 & 39 & \\
\hline \multirow[t]{2}{*}{ INCNFARM } & Yes & 59 & 52 & $.755(N S)$ \\
\hline & No & 41 & 48 & \\
\hline \multirow[t]{2}{*}{ CHEMFERT } & Yes & 12 & 100 & $32.5 * * *$ \\
\hline & No & 88 & 0 & \\
\hline \multirow[t]{2}{*}{ AGRCHEM } & Yes & 41 & 78 & $5.7 * *$ \\
\hline & No & 59 & 22 & \\
\hline \multirow[t]{2}{*}{ ORGFERT } & Yes & 71 & 57 & $.2825(\mathrm{NS})$ \\
\hline & No & 29 & 43 & \\
\hline \multirow[t]{3}{*}{ PESTPROB } & Ape & 53 & 17 & $2.167 * *$ \\
\hline & Pig & 22 & 31 & \\
\hline & Monkey & 25 & 52 & \\
\hline
\end{tabular}

$* *$ and $* * *$ is significant at $\mathrm{p}<.05$ and $\mathrm{p}<.01$ respectively

Improved seed is also another discrete variables in the study area. The survey result realizes that households who use improved seed have the chance to be food secure than those who do not use. With regard to this the statistical analysis of sampled households data shows 
that $12 \%$ of food insecure and 89 of \%food secured households uses improved seed where as $88 \%$ of food insecure and $11 \%$ of food secured households do not utilize it. This difference in percentage and the value of chi square realizes that there is a significance relationship between using improved seeds and food insecurity of the household. This result supports the finding of Beyene and Muche (2010).

Tables 5: Responses categories of coping strategies or mechanisms at initial and severe stage of food insecurity in sampled households.

\begin{tabular}{lcc}
\hline A. Range of coping strategies in rank during initial & Number & $\%$ \\
stage by food insecure households & 65 & 76.5 \\
1st Reduce size of meals & 45 & 53 \\
2nd Reduce number of meals & 40 & 47 \\
3rd Sale of fire wood/charcoal & 30 & 35.3 \\
4th Borrow cash or grain & Number & $\%$ \\
B . Range of coping strategies in rank during & 70 & 82 \\
severe stage by food insecure households & 55 & 79 \\
1st sale of large live stocks & 45 & 53 \\
2nd ate less preferred food & 30 & 35 \\
$3^{\text {rd }}$ migration & & \\
$4^{\text {th }}$ sale of production equipment & &
\end{tabular}

Like improved seed, chemical fertilizer is also the other agricultural input that was assessed to test whether it has a relationship with the household food insecurity situation. From survey result about $62 \%$ of the respondents reported to have used chemical fertilizer in the last cropping season, of which food secure households constitute $52 \%$ and food insecure, made up $10 \%$ of the non-users. It was also found that $12 \%$ of food insecure and $100 \%$ of food secure households used chemical fertilizer where as other $88 \%$ of food insecure and $0 \%$ of food secure households were those do not utilize this input in their production. (Table4). In light of this the statistical analysis of the chi square value showed that there is a significant percentage difference between households food security and insecurity .i.e. the amount of fertilizer used is determine the individuals to be food secure and insecure in the survey area and using chemical fertilizer in general is found to influence food insecurity situation of the household negatively, meaning as they use fertilizer their probability to become food secure increases. This finding is in line with Asmelash (2014); Beyene and Muche (2010); Hossain and Singh(2000).

Sources of income of sampled households: The source of income of the sampled households was the other variable which was examined to check if it has a relationship with household's food insecurity problem. From the survey result the households get income from non-farm, on-farm and off farm activities and the result shows that there is no significance percentage difference between food secured and insecure households in relation to the sources of their income. Accordingly $65 \%$ of food insecure households and $57 \%$ of food secured households get income from non-farm activities where as $35 \%$ of food insecure and $43 \%$ of food secured households don't get income from non-farm activities in the study areas. 
In addition $53 \%$ of food insecure and $61 \%$ of food secured, $59 \%$ of food insecure and $52 \%$ of food secure households get income from off farm and none farm activities, respectively. The statistical chi square value analysis shows that there is no significant relationship between food insecurity and sources of income in selected area.

Animal and Pest Problem: In the study area there are major animals and pest that affect crop production of the farmers. Ape, monkey and pig were the most common production constraints in the area. Those animals and insects which have adverse effects on the house hold production and productivity determine individuals or households to be food secure or insecure in the survey area. From survey result about $53 \%$ foods insecure and $17 \%$ food secured, $22 \%$ food insecure and $31 \%$ secured and $25 \%$ food insecure and $52 \%$ secured households were those affected by ape, pig and monkey respectively. The statistical analysis of the chi square value also realizes that there is significance linkage between the household food insecurity and animal and pest problem. The study conducted by Bimerew and Beyene (2014); Zakari and Song (2014) supports this finding.

Household coping strategies: As indicated in various part of this study some farmers/households in the study area have been affected by various factors that are related to demographic and socioeconomic factors which cause tremendous decline in crop yield induced food insecurity. Different literature show that, In the face of such adverse conditions households usually engage themselves in several mechanisms in order to escape during the initial and severe stages of food shortages. Usually households relied on consumption-based coping strategies when they faced with food shortages (Reardon, et al., 1988; Gebrehiwot and Vander veen, 2014; Abdulla, 2015).

With regard to this study. the sampled households were asked whether they consume less preferred food, whether they reduce the quantity of food served in the household as well as whether the members of the households skipped meals for the last seven days and what coping strategies they employ in order to escape during the initial and the severe stages of food crisis. Accordingly, the sample households responded as they utilize different strategies at different stages in order to escape during the food insecurity issues. The survey result shown that the food insecure households respond differently at different stages of food shortage. Reducing size $(76.5 \%)$ and number of meals $(53 \%)$, sale of fire wood or charcoal to buy food (47) and borrow cash/grain from relatives or friends (35.3) as their 1st, 2nd, 3rd, and 4th rank of coping strategies at initial stages of food insecurity, respectively.

Likewise they respond about their coping strategy during sever food shortage and unlike the initial stage of food shortage, the households respond to the severe stage of food Shortage in a different way. Selling large livestock's, eating less preferred foods (mainly Enset), migration and sales of production equipment are used as their 1st, 2nd, 3rd, and 4th rank of coping strategies at severe stages of food insecurity respectively.

As conclusion, food secure and insecure households were identified based on the calorie intake extracted from the size and pattern of food consumption of sample household. Potential variables presumed to determine state of food insecurity at household level were analyzed with descriptive statistics in comparing with the means of each variable which were affected by those constraints in terms of continuous variable and $t$ - value to decide the relationship between food insecurity and the independent variables. From the result of the survey $57.5 \%$ and $42.5 \%$ of sample households were found to be food secure and food insecure, respectively. with regard to the factors determine the food insecurity situation of the households: total assets, family sizes and number of oxen owned were the continues 
variable which were found to significantly influences household food security where as sex, improved seed, chemical fertilizer, animal and pest problem were the categorical variables that were found to be significant. From both categorical and continues significant variables, the amount of assets, oxen ownership, use of chemical fertilizer and improved seed were found to have positive relationship with the households food insecurity. With regard to their coping mechanisms, vulnerable households in the study area use different strategies at initial and severe stage of food shortage. Reduced size of meals, reduced number of meals, selling fire wood were $1^{\text {st }}, 2^{\text {nd }} \cdot 3^{\text {rd }}$ and $4^{\text {th }}$ respectively which were utilized by food insecure households in order to escape during initial stage of food insecurity whereas sale of large livestock, migration and sale of production equipment were $1^{\text {st }}, 2^{\text {nd }}, 3^{\text {rd }}$ and $4^{\text {th }}$ respectively utilized by the vulnerable households during severe stage of food shortages .

\section{REFERENCES}

A Case Study from Adama Town, Central Ethiopia Journal of Sustainable Development in Africa (Volume 12, No.3, 2010).

Abafita, J., \& Kim, K. R. (2014). Determinants of household food security in rural Ethiopia: An empirical analysis. Journal of Rural Development/Nongchon-Gyeongje, 37(10712016-86950),129-157.

Abdulla, A. M. (2015). Determinants of household food security and coping strategies: The case of Bule-Hora District, Borana Zone, Oromia, Ethiopia. European Journal of Food Science and Technology, 3(3), 30-44.

Abu, G. A., \&Soom, A. (2016). Analysis of factors affecting food security in rural and urban farming households of Benue State, Nigeria. International Journal of Food and Agricultural Economics (IJFAEC), 4(1128-2016-92107), 55-68.

Abu, G. A., \&Soom, A. (2016). Analysis of factors affecting food security in rural and urban farming households of Benue State, Nigeria. International Journal of Food and Agricultural Economics (IJFAEC), 4(1128-2016-92107), 55-68.

Aidoo, R., Mensah, J. O., \&Tuffour, T. (2013). Determinants of household food security in the Sekyere-Afram plains district of Ghana. European Scientific Journal, 9(21).

Alem S., (2007) Determinants of Food Insecurity in Rural Households in Tehuludere Woreda , South Wello Zone of The Amhara Region Addis Ababa University School Of Studies Master's Thesis.

Asmelash, M. (2014). Rural household food security status and its determinants: The case of Laelaymychew Woreda, Central Zone of Tigrai, Ethiopia. Journal of Agricultural Extension and Rural Development, 6(5), 162-167.

Beyene, F., \&Muche, M. (2010). Determinants of food security among rural households of Central Ethiopia: An empirical analysis. Quarterly Journal of International Agriculture, 49(892-2016-65219), 299-318.

Beyene, F., \&Muche, M. (2010). Determinants of food security among rural households of Central Ethiopia: An empirical analysis. Quarterly Journal of International Agriculture, 49(892-2016-65219), 299-318.

Beyene, F., \&Muche, M. (2010). Determinants of food security among rural households of Central Ethiopia: An empirical analysis. Quarterly Journal of International Agriculture, 49(892-2016-65219), 299-318. 
Beyene, F., \&Muche, M. (2010). Determinants of food security among rural households of Central Ethiopia: An empirical analysis. Quarterly Journal of International Agriculture, 49(892-2016-65219), 299-318.

Bimerew, T. G., \&Beyene, F. (2014). Factors influencing rural household food insecurity: The case of Babile district, East Hararghe Zone, Ethiopia. Journal of development and agricultural economics, 6(4), 149-158.

Bogale, A., \&Shimelis, A. (2009). Household level determinants of food insecurity in rural areas of Dire Dawa, Eastern Ethiopia.African Journal of Food, Agriculture, Nutrition and Development, 9(9).

Bose, A. A. (2018). Determinants of Food Security Status among Irrigated Vegetable Farmers in Northern Agricultural Zone of Bauchi State, Nigeria.

Central Statistical Agency (CSA) (2007). "Ethiopia Demographic and Health Survey PreliminaryReport".http://www.csa.gov.et/text_files/Ethiopia_prelim_without_vaccinat ion_final.pdf

Central Statistical Agency of Ethiopia (2010) Population andHousing Census Report-Country - 2007. Addis Ababa: CSA

Diallo, A., \&Toah, M. (2019). A. Determinants of Food Insecurity among Maize Farming Households in the Southern Region of Mali. J. Food Secur, 7, 151-158.

Ehebhamen, O. G., Obayelu, A. E., Vaughan, I. O., \&Afolabi, W. A. O. (2017).Rural households' food security status and coping strategies in Edo State Nigeria.International Food Research Journal, 24(1).

Endalew, B., Muche, M., \&Tadesse, S. (2015). Assessment of food security situation in Ethiopia: A Review. Asian Journal of Agricultural Research, 9(2), 55-68.

Eshetu, F., \&Beshir, M. (2017).Dynamics and determinants of rural-urban migration in southern Ethiopia. Journal of Development and Agricultural Economics, 9(12), 328-340.

FAO, 2014. Ethiopia: Prevalence of Undernourishment and the State of Food Insecurity in (2012-2014).

FAO, 2015. State of Food Insecurity in the World. Food and Agriculture Organization of the United Nations, Rome. State

Frehiwot F., 2007: Food Insecurity and Its Determinants in rural Households in Amhara region, AThesis presented to the school of graduate studies Addis Ababa University.

Gebre, G. G. (2012). Determinants of food insecurity among households in Addis Ababa city, Ethiopia. Interdisciplinary Description of Complex Systems: INDECS, 10(2), 159-173.

Gebrehiwot, T., \& van der Veen, A. (2014).Coping with food insecurity on a micro-scale: Evidence from Ethiopian rural households. Ecology of food and nutrition, 53(2), 214240.

Guled A.,2006. Food Insecurity and Copping Strategies of Agro-Pastoral Households in Awbare Woreda, Somali Region, Ethiopia. M. Sc. Thesis Presented to the School of Graduate Studies of Haramaya University. 109 pp.Alemaya, Ethiopia.

Haile, H.K, Alemu, Z.G and KUDH land G. (2005). Causes of household food in security in Koredagaga peasant and Association, Oromilya zone, Ethiopia, University of Free State.

Hossain, M., \& Singh, V. P. (2000). Fertilizer use in Asian agriculture: implications for sustaining food security and the environment. Nutrient Cycling in Agroecosystems, 57(2), 155-169. 
Joshi, G. R., \& Joshi, N. B. (2016).Determinants of household food security in the eastern region of Nepal. SAARC Journal of Agriculture, 14(2), 174-188

Khan, Q., Umar Farooq, M., \&RizwanYaseen, M. (2018). Socioeconomic Determinants of Food Security: Evidence from Jhang District of Punjab, Pakistan. European Online Journal of Natural and Social Sciences: Proceedings, 7(3 (s)), pp-109

Leza, T., \& Kuma, B. (2015). Determinants of rural farm household food security in Boloso Sore District of Wolaita Zone in Ethiopia. Asian Journal of Agricultural Extension, Economics \& Sociology, 57-68.

Lopéz-Carr, A. C., Lopéz-Carr, D., Grant, L., \& Weeks, J. (2017).Using spatial, hierarchical, and econometric models in urban data-poor areas to examine food security.Plurimondi, (17).

Maharjan, K. L., \& Khatri-Chhetri, A. (2006). Household food security in rural areas of Nepal: Relationship between socio-economic characteristics and food security status (No. 10042016-78861).

Mallick D, Rafi M (2010) Are female-headed households more food insecure? Evidence from Bangladesh. World Dev 38(4):593-605. doi:10.1016/j.worlddev.2009.11.004

Mesas M., (2010): Food Security Attainment Role of Urban Agriculture:

Muche, M., Endalew, B., \&Koricho, T. (2014).Determinants of household food security among Southwest Ethiopia rural households. Food Science and Technology, 2(7), 93-100

Omotayo, A. O., Ogunniyi, A. I., Tchereni, B. H., \&Nkonki-Mandleni, B. (2018). Understanding the link between households' poverty and food security in South West Nigeria.The Journal of Developing Areas, 52(3), 27-38.

Oyekale, T. O., Ayegbokiki, A. O., \& Adebayo, T. Y. (2017).Analysis Of Rural Households' food Security Status In Ogun State, Nigeria .Journal of Agribusiness and Rural Development, 2017(1644-2017-1000).

Reardon, T., Matlon, P., \& Delgado, C. (1988).Coping with household-level food insecurity in drought-affected areas of Burkina Faso. World Development, 16(9), 1065-1074.

Shumetie, A., \&Alemayehu, M. (2019). Poverty and Food Security Effects of Climate Variability on Smallholders: The Case of Western Hararghe Zone, Ethiopia. In Efficiency, Equity and Well-Being in Selected African Countries (pp. 185-198). Springer, Cham

Sseguya, H., Mazur, R. E., \& Flora, C. B. (2018). Social capital dimensions in household food security interventions: implications for rural Uganda. Agriculture and human values, 35(1), 117-129.

Szabo, S., Hossain, M. S., Adger, W. N., Matthews, Z., Ahmed, S., Lázár, A. N., \& Ahmad, S. (2016). Soil salinity, household wealth and food insecurity in tropical deltas: evidence from south-west coast of Bangladesh. Sustainability science, 11(3), 411-421.

Tefera, T., \& Tefera, F. (2014). Determinants of households food security and coping strategies for food shortfall in Mareko District, Guraghe Zone Southern Ethiopia. Journal of Food Security, 2(3), 92-99.

Teklay N, Aynalem S, Nega AR. Determinants and coping strategies of household food insecurity evidence from agro pastoralists of Afar Region (Zone Two) Addis Ababa. J Poverty Invest Dev 2015;12:1-11

Tibesigwa, B., \&Visser, M. (2016). Assessing gender inequality in food security among smallholder farm households in urban and rural South Africa. World Development, 88, 3349. 
Titus, B., \&Adetokunbo, G. (2007). An analysis of food security situation among Nigerian urban households: Evidence from Lagos State, Nigeria. Journal of Central European Agriculture, 8(3), 397-406.

UNDP. (2014). ETHIOPIA: Quarterly key economic and social indicators. Addis Ababa, Ethiopia: United Nations Development Program

United Nation, 2010. Food Assistance Needs Rising for 2010, UN Relief Wing Reports. UN News Service. 3, February, 2010.

WMO (2019), world meteorological organization, Poor rainfall threatens food security in Greater Horn of Africa

Zakari, S., Ying, L., \& Song, B. (2014). Factors influencing household food security in West Africa: The case of Southern Niger. Sustainability, 6(3), 1191-1202.

Zhou, D., Shah, T., Ali, S., Ahmad, W., Din, I. U., \&Ilyas, A. (2019).Factors affecting household food security in rural northern hinterland of Pakistan. Journal of the Saudi Society of Agricultural Sciences, 18(2), 201-210.

Received: $12^{\text {th }}$ December, 2019; Accepted: 24 ${ }^{\text {th }}$ April, 2020; First distribution: $30^{\text {th }}$ July 2020; Published $14^{\text {th }}$ October 2020. 